\title{
Dutch win a reprieve over threatened lab closing
}

Munich. A decision to close one of the Netherlands most important research institutes, the Institute of Applied Radiobiology and Immunology (IARI), has been postponed following a government decision this week to look for another solution. The postponement, precipitated by a major outcry from Dutch scientists, gives hope that the institute and its world-renowned primate centre have a chance of reprieve.

Problems started when the recession-hit government asked the Netherlands' organi-

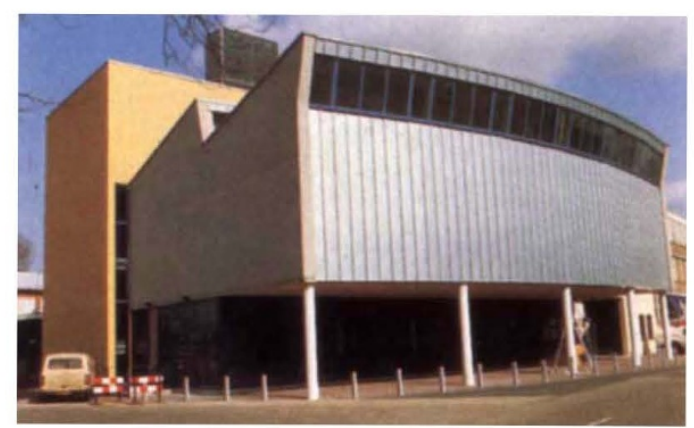

The new Freddie Mercury AIDS centre, part of the threatened ITRI research institute.

zation for applied research, the TNO, to generate more of its own income from industrial contracts; overall state funding for TNO's 25 institutes was reduced slightly in real terms this year, but much steeper cuts have been proposed for 1993. The TNO board of directors targeted ITRI for reorganization because it was running at a severe financial loss. But the scientific community has been quick to defend the institute, which specializes in diseases such as AIDS and malaria; concerted pressure has forced the government to look again at its plans.

The forerunner of ITRI, the Radiobiological Institute, founded in 1956, was internationally renowned for its work under director Dirk van Bekkum on bone marrow transplantation, leading to the world's first successful treatment for aplastic anaemia. Van Bekkum went on to apply the research team's experience with nonhuman primates more broadly, and founded the Dutch Primate Centre in the early 1970s. The centre provided animals for wider studies at the research institute on infectious and autoimmune diseases.

But the running of two units was too expensive for the TNO management. In 1990, it decided to reunite the Radiobiological Institute and the Primate Centre, and over the next year 50 of the 220 staff were made redundant. But by 1992, the financial problems of ITRI were worse. In early summer
ITRI director Joost Haaijman was ordered by the TNO board of directors to offer a reorganization plan that would erase an estimated DFI 3.7 million (US\$2 million) deficit.

When Haaijman's plans were judged to be too moderate, he was replaced with a 'professional reorganizer', Jaap Geenen, whose more drastic plan involves closure of ITRI, with the loss of at least 70 staff, and merging of some of the research projects. Remaining staff would be transferred to the neighbouring TNO Medical Biological Laboratory. In addition, the Geenen plan suggests that the animal facilities be completely separated from research activities and transformed into an independent 'profit centre' for contract research. The plan was put forward two weeks ago to ITRI's 'employees' board', an elected body whose advice on changes in employment conditions must, according to Dutch law, be sought. The board has until the end of next week to put its case.

TNO at present sees no alternative to drastic action, given the government cutbacks in research funding. Health research in any case fits uneasily into TNO's portfolio of market-orientated technology centres; there is no market demand for much of the medical/biological research into the causes of diseases such as AIDS, malaria and multiple sclerosis, it says.

But Dutch researchers do not intend to let one of their leading research institutes go quietly. They are also dismayed at the speed of events - only months between the first announcement and the final decision which leaves no time to look at realistic options such as European Communities funding.

The Dutch government has been taken by surprise by the force of the objections. More than 80 letters of support for ITRI have been received and questions have been asked in parliament. In response, Jo Ritzen, Minister for Education and Science, has given the researchers what they wanted - a breathing space. Ritzen is setting up an international committee, to be coordinated independently by the Dutch Royal Academy of Sciences, to reassess the international importance of ITRI and look for ways of saving it. But the governments has not said it will provide any more money itself.

TNO is now considering how it will handle the delay the government's action will force on its plans for ITRI and its primate centre. One TNO official asks: "Is the government prepared to pay for the centre in the meantime?" Alison Abbott

\section{Biotechnology loses another battle in Germany}

Munich. Hoechst, Germany's largest chemical company, has been blocked once again in its attempt to operate its human insulin plant. Permission granted in 1990 for the plant was last week revoked on a legal technicality one more event in a long chain of delaying actions that have typified the eight-year battle to produce genetically engineered insulin in the German state of Hessen, which is dominated by the Green party.

Hoechst first applied for a licence for a human insulin plant in 1984, but five years of legal wrangling, with approval being alternately granted then revoked, led to a seemingly final decision against Hoechst in 1989 by the regional government of Hessen, one of Germany's 16 federal states. Hessen stated that there was "no sufficient statutory basis for the use of gene technology in Germany". During this time, other companies wanting to use such technology moved out of Germany to more politically sympathetic environments (see Nature 359, 93, 1992); but Hoechst had already invested too much in its project in Frankfurt. Finally, the advent of the German Gene Manipulation Act in 1990 provided the opportunity for a reversal of the decision, in what Hoerchst believed to be the final stage of the battle.

But this was not the end of the story. According to the gene law, the biological system that Hoechst plans to use for engineering insulin is defined as posing "no risk for human health or the environment". This meant that heat inactivation of the waste water, a precondition of the 1990 approval, was no longer necessary. Hoechst put in a further proposal for a modified plant which excluded the inactivation step.

Approval for the modified plant was granted in July. But further objections were received by the Hessen environment ministry and the project was postponed once more until October. In the meantime, Hoechst appealed to Germany's administrative courts against Hessen's stalling tactics. But that backfired - the court instead ruled last week that the July authorization was invalid on detailed technical grounds - and Hoechst was back where it started.

Hessen must now decide whether to tidy up its authorization for the modified plant according to the directive issued by the administrative court, or to scrap it and start the process from scratch. It must also consider again the formal objections.

In the meantime, Hoechst claims to be losing DM3.5 million (US\$5.2 million) a month in lost income from the plant, and people suffering from diabetes are using imported genetically engineered human insulin from the United States and Denmark.

Alison Abbott 